\title{
Article
}

\section{Forum: Literature and Language Awareness: Using Literature to Achieve CEFR Outcomes}

Jones, Christian and Carter, Ronald

Available at http://clok.uclan.ac.uk/3320/

Jones, Christian and Carter, Ronald (2012) Forum: Literature and Language Awareness: Using Literature to Achieve CEFR Outcomes. Journal of Second Language Teaching and Research, 1 (1). pp. 69-82. ISSN 2045-4031

It is advisable to refer to the publisher's version if you intend to cite from the work.

For more information about UCLan's research in this area go to http://www.uclan.ac.uk/researchgroups/ and search for < name of research Group>.

For information about Research generally at UCLan please go to http://www.uclan.ac.uk/research/

All outputs in CLoK are protected by Intellectual Property Rights law, including Copyright law. Copyright, IPR and Moral Rights for the works on this site are retained by the individual authors and/or other copyright owners. Terms and conditions for use of this material are defined in the policies page.

\section{CLoK}

Central Lancashire online Knowledge www.clok.uclan.ac.uk

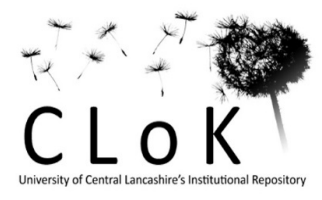




\title{
LITERATURE AND LANGUAGE AWARENESS: USING LITERATURE TO ACHIEVE CEFR OUTCOMES
}

\author{
Christian Jones, University of Central Lancashire
}

Ronald Carter, University of Nottingham

\begin{abstract}
This article sets out to explore why literature (used in this article to mean poetry, plays, short stories or novels) is often a marginalised resource in EFL classrooms, even though the Common European Framework of References for Languages (CEFR) suggests it should have a role in the classroom. It first reports on the results of a questionnaire investigating English teachers' attitudes towards using literature in the classroom. After a discussion of these results, it explores some ways in which the use of literature can be linked to CEFR outcomes in a practical teaching framework which teachers can apply to literature they choose to teach.
\end{abstract}

: Literature, language teaching, language awareness, CEFR

\section{Introduction}

There have been a number of theoretical arguments for using literature in communicative classrooms since the nineteen eighties (for example, Brumfit and Carter 1986; Maley and Duff, 1990; Carter and McRae, 1996; Gilroy and Parkinson, 1997; Chan, 1999; Hall, 2005; Paran, 2006; Watson and Zyngier, 2006) and a number of activities and materials developed for using literature in the classroom (for example, Maley and Moulding 1985; Collie and Slater, 1987; McRae and Vethamani, 1999). Despite this, it remains a somewhat marginalised resource, featuring in only a limited way in general English textbooks, most often reserved for higher level learners and commonly employed for unimaginative reading comprehension. In an age when most textbooks are linked to the outcomes of the CEFR this is surprising, particularly when the ability to read literature features strongly in many of its outcomes. The following 'can do' statements, taken from the common reference levels, demonstrate this clearly:

'I can understand contemporary literary prose' (B2 common reference levels reading descriptor, CEFR, 2010, p 27)

'I can understand long and complex factual and literary texts' (C1 common reference levels reading descriptor, CEFR, 2010, p27). 
A detailed look at the CEFR reveals that literature is seen as a central resource in achieving its goals: 'It is much hoped that teachers of literature at all levels will find sections of the framework relevant to their concerns and useful in making their aims and methods more transparent' (CEFR, 2010, p.56). Literature is discussed in broad and specific terms. It is described as something which helps to develop socio-cultural knowledge and aesthetic enjoyment of language (CEFR, 2010, p.56, p.103) and is also linked to specific outcomes, such as the following: 'Can write clear detailed descriptions of real or imaginary events and experiences' (B2 Creative writing descriptor, CEFR, 2010, p.62). This suggests that if we are to judge a learner's competence against the CEFR, literature should play a much less marginalised role in the classroom. This article aims to make a contribution to this debate through a discussion of a small sample of English teachers' attitudes to using literature, the difficulties they face and a suggested teaching framework which aims to give an easy route for teachers to use literature, should they choose to do so.

\section{The attitude of teachers towards using literature}

Since literature does have a role to play in meeting CEFR outcomes, what, then, are the best ways of achieving this in the classroom? In order to investigate how teachers themselves view using literature as a resource, a qualitative attitudes questionnaire was distributed to twelve English language teachers at the University of Central Lancashire, all involved in teaching a range of both EFL and EAP classes from intermediate (B1) to advanced (C1) levels. The intention was to obtain a snapshot of teachers' views, both positive and negative, in order to then make suggestions about using literature in the classroom. The sample was partly based on convenience (Dornyei, 2007), i.e. which teachers were available at the time, but there was also an attempt to survey teachers with a range of teaching experience.

Six of the teachers had between 0-5 years of teaching experience and six had from 5-17 years experience. Qualifications ranged from initial certificate level only, through to diploma and MA level. Two of the respondents are currently studying for PhDs. We would not wish to claim that such a sample is representative of all English language teaching institutions but we can suggest it is fairly representative of the teachers of EFL/EAP at this university and could therefore be generalized to similar teaching contexts.

The basic design of the questionnaire was modeled on a similar qualitative design used to elicit learners' attitudes towards learning English (Schmitt et al. 2004:p.77). A statement 
which will elicit a judgment based on the respondent's opinion is stated and a response is given on a five or six point scale, from 'agree' to 'strongly disagree'. In this study, an identical six point scale to Schmitt et al. was originally used so that teachers could answer 'strongly disagree', 'disagree', 'slightly disagree', 'partly agree', 'agree' and 'strongly agree'. After piloting, this design was amended to a five point scale from 'strongly disagree' to 'strongly agree' with an option for teachers to answer 'not sure', as feedback indicated that this was an option that respondents wanted. The statements themselves were chosen to elicit a range of general opinions about the use of literature, rather than specific aspects of the CEFR, as it was felt that this would provide a richer set of data to analyse. The results of the questionnaire can be seen in Table 1, below. 
Table 1. Attitudes towards using literature in the English language classroom

\begin{tabular}{|c|c|c|c|c|c|}
\hline $\begin{array}{l}\text { Attitudes towards using literature in the English } \\
\text { language classroom }\end{array}$ & 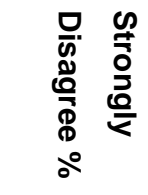 & 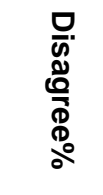 & 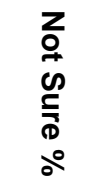 & 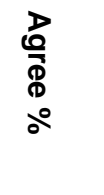 & 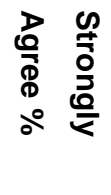 \\
\hline $\begin{array}{l}\text { 1. Literature is a useful source of classroom } \\
\text { material }\end{array}$ & & 16.6 & & 75 & 8.3 \\
\hline $\begin{array}{l}\text { 2. Literature is best saved for advanced } \\
\text { learners }\end{array}$ & 25 & 50 & 8.3 & 16.6 & \\
\hline $\begin{array}{l}\text { 3. Textbooks don't feature enough literature as } \\
\text { reading material }\end{array}$ & & 16.6 & 16.6 & 41.6 & 25 \\
\hline $\begin{array}{l}\text { 4. Using literature can help develop cultural } \\
\text { awareness }\end{array}$ & & & & 66.6 & 33.3 \\
\hline 5. Using literature takes a lot of preparation & & 33.3 & 8.3 & 41.6 & 16.6 \\
\hline $\begin{array}{l}\text { 6. Most students will react positively to literature } \\
\text { if used in class }\end{array}$ & 8.3 & & 50 & 33.3 & 8.3 \\
\hline $\begin{array}{l}\text { 7. Not enough classroom time is available for } \\
\text { using literature }\end{array}$ & & 16.6 & 25 & 41.6 & 16.6 \\
\hline $\begin{array}{l}\text { 8. Literature often contains a lot of difficult } \\
\text { cultural references and low frequency language } \\
\text { which students struggle with }\end{array}$ & & 33.3 & & 66.6 & \\
\hline $\begin{array}{l}\text { 9. Understanding literature is not what most } \\
\text { learners need to do } \\
\text { 10. Literature can imorove a learner's awareness }\end{array}$ & 8.3 & 16.6 & 33.3 & 50 & \\
\hline of language use in a helpful context & & & 16.6 & 66.6 & 16.6 \\
\hline
\end{tabular}


In addition to the statements, teachers were also invited to add any additional comments they wished. A selection of the comments is reproduced below:

- Many students arrive with instrumental motivation and as such desire more functional, practical English in the classroom. This often leads to a negative reaction by some students who cannot perceive the relevance of literature in their learning.'

- I have not used literature in the English language classroom as it is not a subject that I am particularly interested in and I feel I would find it hard to motivate students and not pass on my own feelings on the topic.'

- There are simply no literature resources in either of the places I work in... I'm not sure how big a part literature should play in classes but I think it could be an important feature.'

- I am not sure all students would react well to the use of literature if they were on an intensive course limited by time.'

- Using literature is like using any material in class - you have to come at it from an angle that students can connect with - and make sure there is a teaching point in there students should see that there is language being taught in class.'

- 'While I am confident that literature could play a role in increasing learners' cultural awareness, I am also concerned that learners are likely to reject it in favour of studying what they need to succeed in exams.'

- I don't use it too often, although I think it has value.'

- I prefer to advise students to read graded literature in their spare time as there is often not enough time in class to look at literature.'

- ..when teaching general English... it is beneficial for learners to be exposed to literature at every opportunity.'

It is clear from these results that the teachers have clear beliefs about using literature in the EFL classroom. They show that $75 \%$ of these teachers feel that it is a useful classroom resource and $66.6 \%$ felt it can help to develop language and cultural awareness. However, it is also clear that there are concerns that using literature will not meet students' needs, with $50 \%$ of respondents agreeing it was not what students need and $50 \%$ unsure if their learners would react positively to it. These attitudes are encapsulated by the following comments:

- 'While I am confident that literature could play a role in increasing learners' cultural awareness, I am also concerned that learners are likely to reject it in favour of studying what they need to succeed in exams.' 
- 'I am not sure all students would react well to the use of literature if they were on an intensive course limited by time.'

Other worries are that it may be inaccessible and could take a lot of planning time, with $66.6 \%$ of respondents agreeing that it can contain difficult language and cultural references. These results suggest that if teachers decide to use literature, a teaching framework which addresses the main issues raised may be of benefit. The literature chosen needs to be accessible for teachers and students, to overcome the suggestion that it can be culturally and linguistically difficult. Also, it needs to have a clear learning pay-off which matches students' needs, particularly on a course where time is limited. The need for a pay-off suggests there is benefit in linking the use of literature to the CEFR, particularly as many courses, major English language exams and textbooks are now linked to these outcomes.

\section{A teaching framework}

What follows is a description and explanation of three suggested guiding principles for choosing and using literature. The principles entail interesting the learner, involving the learner in the text and creating a learning pay-off. Put together, these can be summarised into a three-point framework of 'access', 'activity', and 'awareness', each of which can be linked to a CEFR outcome. The ideas below exemplify this framework through the use of one sample text and are working towards the broad outcome at B2 level of understanding contemporary literary prose, with more specified outcomes suggested at each stage. The same framework could of course be applied at B1 or C1 levels and although primarily intended for EFL classes, ideas on how it might be adapted for EAP or exams classes are also given. Although these ideas have been used in our classrooms, we cannot claim to have incorporated them into a syllabus or conducted extensive classroom research, so they are offered largely as proposals for teaching and research at this stage.

\section{Access}

Teachers who know their students will easily be able to find texts with topics of interest for them but we also need to find accessible texts which match these interests. It is important, for instance, to make sure that students do not lose the desire to work with a text because interpreting it requires cultural knowledge that they do not have. We can imagine, for example, that our learners may be interested in description of places but many would have difficulty accessing the following description of the British seaside town, Morecambe:

Morecambe was once a rival to Blackpool in the popularity stakes. Then, like New

Brighton on the Wirral, it became a byword for faded glamour.... Most ignominiously 
of all, in 1994, Noel Edmunds opened his ill-judged (insane if you ask me) World of Crinkley Bottom, a theme park based on his reviled but hugely popular TV show. (Maconie ,2008, p.264).

It seems clear that if learners are not aware of the particularly British places and people mentioned here, the image the writer is trying to evoke will be lost on them. This is not to argue for texts which are culturally neutral or bland but rather for ones that do not require extensive explanation of cultural reference points before students can begin to engage with the text. In other words, we are arguing for texts which have an access point for learners. Here is an example of a poem by Bertolt Brecht (1898 -1956), which meets this need. The poem is translated from the German original but we do not consider this to be an issue as it 'works' well as an English text.

\section{Pleasures}

The first look out of the window in the morning

The old book found again

Enthusiastic faces

Snow, the change of the seasons

The newspaper

The dog

Dialectics

Taking showers, swimming

Old music

Comfortable shoes

New music

Writing, planting

Travelling

Singing

Being friendly

(Willett and Manheim, 1987, p.448)

While this text is not, strictly speaking, prose, it is closer to it than many poems will be and it is a short and accessible starting point. The word 'dialectics' needs to be pre-taught, but aside from that, learners do not need any extensive cultural knowledge to access the text 
and do not in fact even need to know it is a poem when they start to engage with it. The language is simple and should be well within the linguistic range of learners at B2 level.

For the teacher, there are also access points into the text, meaning there are ways in which they can easily start to interest learners, without the need for too much time-consuming preparation. One way into this poem might be for the teacher to begin by describing their simple pleasures in life, or students guessing these from pictures. Students could then be given a simple task to think and rank their own top ten pleasures in life before discussing/deciding in groups which student has the most convincing list. Comparison of what is considered a pleasure in different cultural contexts could also be encouraged (see Collie and Martin, 2000, for relevant sample materials with respect to UK cultures).

Access tasks such as this of course serve a purpose of activating schemata and getting learners interested in reading a text. However, they can also be linked to specific outcomes and these can be highlighted to learners. In this case, the activity clearly links to the following outcome described in the 'informal discussion with friends' section of the B2 descriptor 'Can take an active part in informal discussion in familiar contexts, commenting, putting point of view clearly, and evaluating alternative proposals' (CEFR, 2010, p.77). For a range of related activity-based ranking tasks, several with reference to similar accessible short texts, see also Maley and Duff, (1990) and Maley (1999).

\section{Activity}

Carter (1996) describes the 'activity principle' as something whereby 'students actively participate in making the text mean' (p.3). This suggests that learners are not simply given a text and then tasks to comprehend it. Rather, they are given tasks which first help them to construct and thus actively process the text. There are three clear reasons for this: actively involving students with the text also helps to engage them; it also values their ability to act as thinking, creative language users; and it help learners work towards another outcome of the CEFR at B2 level, that learners 'Can read with a large degree of independence' (CEFR ,2010, p.69). Class activities alone will not help learners to read independently of course, but they are a step towards encouraging independence.

If we return to the Brecht poem above, we can demonstrate this more clearly with a simple example. After an access task, students can be given a line each and, working in groups or as a class, they discuss and decide the best order for the lines, before finally comparing to the original poem. They can then discuss whether they prefer their own order or the poet's 
order. Such tasks encourage learners to interact with the text, processing how a text means (McRae, 1991) on the way to understanding what it means.

\section{Awareness}

It is also clear from the teachers surveyed that many learners approach reading texts for some kind of language pay-off and without this, they may perceive that working with literature is a waste of time. In our experience, learners will see this in terms of the lexical, grammatical or phonological features they can pick up from a text. The CEFR is not intended as a document which specifies the language items to be taught at each level but instead gives competency descriptors for each level. At a weaker B2 level, for example, a learner 'shows a relatively high degree of grammatical control. Does not make mistakes which lead to misunderstanding' (CEFR, 2010, p.114). Textbooks and syllabuses will normally specify the exact language which is to be taught at each level but literature can play a key role in helping to develop awareness, something which must be the first step towards gaining grammatical control (see Schmidt, 1990; Lewis, 1993; Fotos, 1994 for studies of how explicit consciousness raising, form-focussed tasks can lead to enhanced grammatical and lexical awareness). Language awareness tasks can help with this by encouraging learners to explore patterns in text and to notice features of the language as well helping them to think in English about English (Bolitho, et al. 2003).

If we look at the same Brecht poem, there are a number of discussion questions we might wish to use as shown in the sample task below:

\section{Language awareness task}

1. What kind of text is this? How do you know?

2. The text contains almost no verbs. Why do you think this is?

3. Why did the writer choose to write 'the newspaper' and not 'newspapers' or 'a newspaper'. How would the text be different if he had written 'newspapers'?

4. Why did he write 'snow' and not 'the snow'?

5. What other adjectives could be used before the word 'shoes'? How would each change the meaning of the text?

6. There are three common patterns in the text, (a) adjective + noun, (b) 'ing' form used as a noun and (c) definite article + noun. Find examples of each in the text. Why is each pattern used here? What effect does each have? 
Such discussions can also be linked to a number of other learning outcomes such as 'Can account for and sustain his/her opinions in discussion by providing relevant explanations, arguments and comments' (Informal discussion with friends B2, CEFR 2010, p.77) and again this can be explained to learners in order that they are clear that these tasks link to both broad and specific CEFR outcomes. Awareness can also be generated by comparison with other texts that are different in content, that are simplified, that are from different registers and genres or, in a distinctively more activity-based frame, through their own transformative writing, re-writing texts themselves from one style to another (Knights and Thurgar-Dawson, 2006).

\section{Adapting the framework for EAP and exam-focussed classes}

As outlined in the discussion above, some learners may be resistant to using literature in class perhaps because they have very instrumental goals such as passing exams or gaining admission to courses in higher education. It is understandable for teachers in these situations to focus primarily on texts which learners may encounter in their tests. However, with a little adaptation, it is possible to use the framework outlined above whilst adapting it to the learners' more instrumental needs. The shift in focus needs to take place at the activity and awareness phases in order for learners of these types to be able to see how these tasks relate to their instrumental goals. One way we might do this with the 'Pleasures' poem is to follow a similar access task and then allow learners to read the text. Following this, the activity can change so that we set up a mini- class discussion task using a table such as the example below. Learners first fill in their own reaction to the text and then find out the reactions of the rest of the class. 
Table 2 Responding to literature

\begin{tabular}{|l|l|l|l|l|l|}
\hline & $\begin{array}{l}\text { Strongly } \\
\text { Agree }\end{array}$ & Agree & Not sure & Disagree & $\begin{array}{l}\text { Strongly } \\
\text { disagree }\end{array}$ \\
\hline $\begin{array}{l}\text { This is an } \\
\text { interesting poem }\end{array}$ & & & & \\
\hline $\begin{array}{l}\text { The ideas in the } \\
\text { text are } \\
\text { interesting }\end{array}$ & & & & & \\
\hline $\begin{array}{l}\text { The text is too } \\
\text { simple }\end{array}$ & & & & & \\
\hline $\begin{array}{l}\text { Anybody could } \\
\text { write this }\end{array}$ & & & & & \\
\hline $\begin{array}{l}\text { The text really } \\
\text { made me think }\end{array}$ & & & & & \\
\hline
\end{tabular}

The students now have a table of data and the main activity can be changed so that they are asked to analyse and write a short report summarising the table; something they are required to do for examinations such as IELTS. Of course, this could be done without the use of literature and we might simply give students a table and ask them to analyse it. However, using literature is perhaps more likely to provoke a response from the students and does of course encourage thinking and discussion in English, a skill all EAP and exam students need to develop and one which can be linked to the academic outcomes outlined in the CEFR. Asking learners to analyse their own opinions also makes the task slightly more meaningful than analysing a table they are simply presented with.

At the awareness stage, the focus may be similar to the task given above but again can shift slightly to adapt to the learners. In this case, a teacher might use the questions as a first step to reviewing the use of zero, definite and indefinite articles, something many learners will need to master in order to improve written and spoken accuracy. Students could first work through questions one to four in the language awareness task given as a first step to 
revising article usage. Learners could then compare the usage in this text to that of other texts such as essays, before revising the rules and asking learners to examine sample exam texts or their own texts for article usage.

\section{Conclusion}

It is clear that the CEFR suggests that literature should play a key part in developing language competence, especially at B2 level. The teachers surveyed in this article believe that literature can be a useful resource for developing language and cultural awareness but have some doubt about how useful students will perceive it to be and concerns about the preparation needed and the classroom time available. We have suggested that one solution could be for teachers to use an access, activity and awareness framework, which can be easily applied to any text and which could help learners not just to appreciate literature but also to use literary texts as a resource for developing language and cultural awareness.

We have also argued that literature can develop a number of skills which we can link clearly to CEFR outcomes to underline the pay-off for learners. Most learners do not want to study literature for its own sake but most would be happy if they could see a clear learning outcome linked to their developing language awareness.

\section{References}

Bolitho, R., Carter, R., Hughes, R., Ivanic, R, Matsuhara, H., \& Tomlinson, B. (2003). Ten Questions about Language Awareness. English language Teaching Journal 57/3, pp.251-259.

Brumfit, C.J., \& Carter, R. (Eds.) (1986). Literature and Language Teaching Oxford: Oxford University Press.

Carter, R., \& McRae, J (Eds.) (1996). Language, Literature and the Learner. Harlow: Longman.

Collie, J., \& Slater, S. (1987). Literature in the Language Classroom. Cambridge: Cambridge University Press.

Collie, J., \& Martin, A. (2000). What's it Like? Life and Culture in Britain Today Cambridge: Cambridge University Press.

Chan, P.K.W. (1999). Literature, Language awareness and EFL. Language Awareness 8(1), pp.38- 50. 
Fotos, S. (1994). Integrating Grammar Instruction and Communicative Language Use through Grammar Consciousness-Raising Tasks. TESOL Quarterly, 28, 2, pp.323340 .

Gilroy, M., \& Parkinson, B. (1997). Teaching Literature in a Foreign Language. Language Teaching 29, pp.223-225.

Hall, G. (2005). Literature in Language Education. London: Palgrave.

Knights, B., \& Thurgar-Dawson, C. (2006). Active Reading London: Continuum.

Lewis, M. (1993). The Lexical Approach. Hove: LTP.

Maconie, S. (2008). Pies and Prejudice In Search of the North.Reading: Random House.

McRae, J. (1991).Literature with a Small ‘'.London: Macmillan.

McRae, J., \& Vethamani, M. (1999). Now Read On.London:Routledge.

Maley, A. (1999). Short and Sweet: Short texts and how to use them. Harmondsworth:

Penguin.

Maley, A., \& Duff, A. (1990). Literature. Oxford: OUP.

Maley, A., \& Moulding, S. (1985). Poem into Poem. Cambridge: CUP.

Paran, A. (2006). Literature in Teaching and Learning: Case Studies in TESOL Practice Alexandria, Va, TESOL.

Schmidt, R.W. (1990). The Role of Consciousness in Second Language Learning. Applied Linguistics Vol.11, no.2, pp.129-158.

Schmitt, N., Dornyei, Z., Adolphs, S., \& Durow, V. (2004). Knowledge and Acquisition of Formulaic Sequences. In Schmitt, N. (Ed.) (2004). Formulaic Sequences: Acquisition, Processing and Use .Philadelphia: John Benjamins, pp.59-86.

The Common European Framework of References for Languages. 2010.

Retrieved from http://www.coe.int/T/DG4/Linguistic/Source/Framework EN.pdf (21 April 2010)

Watson, G., \& Zyngier, S. (Eds.) (2006). Literature and Stylistics for Language Learners:

Theory and Practice. Basingstoke: Macmillan/Palgrave.

Willett,J., \& Manheim, R. (Eds.) (1987). Bertolt Brecht Poems 1913-1956. London: Methuen. 


\section{Biodata}

Christian Jones is a Senior Lecturer in TESOL at the University of Central Lancashire and has previously worked as a teacher and teacher trainer in Japan and Thailand. His main research interests are in spoken discourse analysis, lexis, and the pedagogical treatment of spoken grammar.

Ronald Carter is Professor of Modern English Language at the University of Nottingham. He has written and edited more than 50 books and has published over 100 academic papers in the fields of language and education, language and literature, applied linguistics and the teaching of English, with particular reference to teaching English as a second, foreign or additional language. He has taught, lectured and given consultancies to government agencies and ministries in the field of language education, mainly in conjunction with the British Council, in over thirty countries world-wide.Recent books include: The Cambridge Guide to Teaching English to Speakers of Other Languages (ed with David Nunan) (CUP, 2001), The Routledge History of Literature in English (Routledge, $2^{\text {nd }}$ ed 2002); Language and Creativity: The Art of Common Talk (Routledge, 2004) and Cambridge Grammar of English: A Comprehensive Guide to Spoken and Written Grammar and Usage (with Michael McCarthy) (CUP, 2006). 